Brazilian Journal

of Chemical

Engineering

\title{
CO-TREATMENT OF LEACHATE AND DOMESTIC SEWAGE AND ITS INFLUENCE ON NITROGEN REMOVAL
}

\author{
Fábio Campos $^{1 *}$, Rodrigo de F. Bueno ${ }^{2}$ and Roque P. Piveli ${ }^{1}$ \\ ${ }^{1}$ Universidade de São Paulo, Escola Politécnica, São Paulo, SP, Brasil. E-mail: fcampos@usp.br - ORCID: 0000-0002-8117-789X; \\ ORCID: 0000-0003-0653-0603 \\ ${ }^{2}$ Universidade Federal do ABC, Centro de Engenharia, Modelagem e Ciências Sociais Aplicadas, Santo André, SP, Brasil. \\ ORCID: 0000-0002-6274-3278
}

(Submitted: July 19, 2018 ; Revised: October 30, 2018 ; Accepted: December 17, 2018)

\begin{abstract}
This research investigated the performance of two pilot-scale treatment plants: an activated sludge and a hybrid model type IFAS (Integrated Fixed-Film Activated Sludge), combining sanitary landfill leachate with domestic sewage treatment with the objective of removing organic substances. In order to assess the possible impacts on the treatment, three experimental phases were developed with leachate inputs in the influent composition: $5 \%, 10 \%$ and $20 \%$ of the total load of BOD. As can be seen from the results, even with the highest levels of leachate input, there were no significant changes in the behavior of the biological processes. Regarding the oxidation of nitrogen compounds, expressed in terms of TKN, approximately $90 \%$ removals were observed for the IFAS process in all the phases. In the Activated Sludge process, removal rates during the study were approximately $70 \%$, indicating poor performance. The kinetic coefficients for the autotrophic metabolism related to the Activated Sludge process remained stable, while a progressive decrease was observed for each stage in the IFAS process. In general, the IFAS process presented better performance than the Activated Sludge process in terms of removal efficiency of nitrogen matter, as well as higher operating stability.

Keywords: Leachate; Landfill; Domestic sewage; IFAS; Nitrogen; Respirometric.
\end{abstract}

\section{INTRODUCTION}

Landfill leachate is wastewater of difficult treatability due to the presence of biodegradable organic matter in varying concentrations over time, recalcitrant organic matter, inorganic toxic compounds and high concentration of ammoniacal nitrogen. Disposing the leachate into sewage treatment plants is a solution adopted in many countries. The dilution suffered by inhibiting substances allows the biochemical processes to occur in a more stable and efficient manner (Bassin et al., 2018). Studies have demonstrated that cotreatment of young leachate with municipal wastewater does not adversely affect WWTP performance (Ye et al, 2014; Kalka, 2012). However, if high amounts or unequalized loads of leachate are introduced into the sewage treatment plant (STP), there may be irreversible effects. Low operating costs, as well as the use of existing structures, reinforces the use of this alternative. However, regarding the effluent quality generated by the combined treatment of leachate and wastewater, the variables commonly used to characterize the efficiency achieved by the treatment to remove organic compounds, such as BOD, COD and COT, may not allow an exact distinction between biodegradable organic matter and recalcitrant matter (Campos, 2014; Sivic et al., 2018). Yuan et al. (2016) conducted studies treating a $2.5 \%$ mixture of landfill leachate with sewage in a Sequential Batch Reactor (SBR) and observed an improvement in the biological removal of nutrients. The research of Boccheglieri (2010) on four STPs in São Paulo, concluded that further studies are needed

\footnotetext{
* Corresponding author: Fábio Campos - E-mail: fcampos@usp.br
} 
for fully understanding the implications arising from the combined treatment of leachate and sewage. These may concern various aspects such as the toxicity of biological processes, the sludge quality and the treatment effluent. Klimiuk and Jkulikowska (2006) conducted experiments with batched activated sludge by varying the Hydraulic Retention Time (HRT) with leachate doses ranging from 5 to $25 \%(\mathrm{v} / \mathrm{v})$ in sewage. A $97.5 \%$ organic matter removal was obtained with a 2-day HRT. Çecen and Cakiroglu (2001) treated leachate from the Gaziantep - Turkey landfill, combined with sewage in the batched activated sludge process, in a ratio ranging from $5 \%$ to $20 \%(\mathrm{v} / \mathrm{v})$. The authors concluded that a percentage of leachate over $20 \%$ of the treated influent wastewater or equal to $50 \%$ of the initial COD load compromised the efficiency of the treatment. Ehrig (1998) carried out laboratory works with the activated sludge process, in which leachate was added in a proportion of $1 \%$ to $16 \%$ of the sewage blend's volume. The BOD and COD values increased in the final effluent with greater proportions of added leachate, possibly as a result of phosphorus deficiency and the addition of non-biodegradable organic load from the leachate. Diamadopoulos et al. (1997) proposed using an activated sludge reactor, operating in sequencing batch in laboratory, to treat the combined effluents. With the addition of leachate (BOD 2000-4700 mg.L. ${ }^{-1}$, COD 4700-12000 mg.L $\mathrm{L}^{-1}$ and $\mathrm{N}-\mathrm{NH}_{3} 405-920 \mathrm{mgN} . \mathrm{L}^{-1}$ ) in a $10 \%$ blend volume, $70 \%$ to $98 \%$ BOD removal and $35 \%$ to $50 \%$ total nitrogen removal were obtained. McBean et al. (1995) recommended a leachate and wastewater volume ratio below $2 \%$. They stated that adding large volumes of leachate to the sewage treatment system may result in treated effluents with high concentrations of organic matter and ammoniacal nitrogen. Seeking to study the nutrient removal in combined treatment of leachate and wastewater, Boyle and Ham (1974) demonstrated that, through an activated sludge process with extended aeration, leachate with COD rates of up to $10,000 \mathrm{mg} . \mathrm{L}^{-1}$ can be treated in a mixture of $5 \%(\mathrm{v} / \mathrm{v})$ with sanitary sewage without changing the quality of the final effluent. Among the new treatment technologies developed in recent decades, the hybrid process Integrated Fixed-Film Activated Sludge (IFAS) has not yet been fully exploited in sanitary landfill leachate treatment. The IFAS process promotes biomass growth in the aeration tank of an activated sludge system to increase its capacity and to improve its performance. In this process, the concentration of active solids in the biological sludge can be significantly increased by the introduction of mobile biomedia in an activated sludge system (Ødegaard et al., 1994; Daigger et al., 2018). Inside the biomedia, a highly specialized biomass is developed for each type of condition imposed on the reactor, regardless of the relative age of the sludge biomass in suspension. Similar to the contribution of biomass attached to the support environment, the required concentration of biomass in suspension in the reactor is lower, thus reducing the load of suspended solids to the secondary clarifiers and preventing setbacks to effluent clarification (WEF, 2008). The IFAS process can be considered a good alternative when the goal is to increase treatment capacity of older activated sludge systems, or when incorporating the removal of nutrients, particularly nitrogen, is needed. Nitrifying bacteria for biofilm retention allow operating the system with low age sludge (Regmi et al., 2011; Campos et al., 2017), thus generating savings to the treatment. Brennan et al. (2017) observed no inhibition in the nitrification process in terms of ammonia while treating domestic sewage combined with leachate, when applying $40 \%$ to $50 \%$ of the volumetric load affluent to the station. Canziani et al. (2006) evaluated the treatment of leachate from an old landfill of Northern Italy by using a combined MBR-MBBR system with $37.5 \%$ of the total tank capacity regarding the MBBR, which was operated seeking to promote nitrification. Approximately $90 \%$ of ammonia removal was obtained with application rates ranging from 5 to $120 \mathrm{gN}-\mathrm{TKN} . \mathrm{kgTSS}^{-1} \cdot \mathrm{d}^{-1}$ Welander et al. (1997) evaluated a MBBR system with leachate from the landfill of Hyllstofia (Sweden), in operation since 1975 . The process consisted of a leachate volume of $60 \%$ of the filling capacity, operating with an HRT ranging from 2 to 5 days and at $80 \%$ of DO saturation. Throughout the study, it reached $98 \%$ of nitrification, with application rates up to $11 \mathrm{~g} N-\mathrm{NH}_{4}^{+} \cdot \mathrm{m}^{-3} \cdot \mathrm{h}^{-1}$. The researchers concluded that rates of up to $40 \mathrm{~g} \mathrm{~N}-\mathrm{NH}_{4}^{+} \cdot \mathrm{m}^{-}$ ${ }^{3}$ reactor $^{-1} \cdot \mathrm{h}^{-1}$ could be applied without the risk of biomass loss or of compromising the treatment efficiency. This study aimed to evaluate the performance of two bioreactors, one operated by conventional activated sludge, and the other by the IFAS process. Organic matter and nitrogen removal were assessed together with the kinetic behavior after the mixture of leachate with domestic sewage.

\section{MATERIALS AND METHODS}

\section{Pilot Plant}

The research was conducted through a pilotscale experiment consisting of two activated sludge bioreactors made of acrylic sheet, differing from each other by the introduction of mobile biomedia in one of the reactors for attached biomass development, therefore configuring a hybrid IFAS (Integrated Fixedfilm Activated Sludge System) system. The pilot unit, which operated as conventional activated sludge was called LAC, while the other was named LAI. The aeration tank was divided into two compartments: the first with a net volume of $270 \mathrm{~L}$ was equipped with a mixer, which operated as an anoxic pre-denitrification chamber. The second compartment, with a net volume 
of $800 \mathrm{~L}$, operated as an aerated chamber, with four thin membrane bubble diffusers installed at its bottom to distribute the air provided by the compressor to maintain the DO concentration in an interval of 1.0$3.0 \mathrm{mgO}_{2} \cdot \mathrm{L}^{-1}$ in the LAC pilot, and $3.0-4.0 \mathrm{mgO}_{2} \cdot \mathrm{L}^{-1}$ in the LAI pilot. The secondary clarifier, with a surface area of $0.785 \mathrm{~m}^{2}$ and net volume of $1.47 \mathrm{~m}^{3}$, had a circular cross-section, with a wall scraper powered by an electric motor. The pilot units also had two elevating sets, one for the sludge to return from the secondary clarifier to the anoxic chamber, and the other to promote internal recycling of the sludge from the aeration tank to the anoxic chamber. Both of the bioreactor chambers in the LAI pilot had biomedia installed. K1 product was used, manufactured by the Anox Kaldnes ${ }^{\circledR}$ company, currently owned by Veolia Water group, with specific surface area (protected) of $300 \mathrm{~m}^{2} \cdot \mathrm{m}^{-3}$ of support material. The filling percentages with biomedia of the anoxic and aerobic chambers were $30 \%$ and $50 \%$, respectively. Acidity, DO and temperature sensors were installed in the bioreactors. Figure 1 represents a global view of the pilot units.

\section{Experimental Design}

Leachate from the Caieiras Landfill (CTR-Caieiras). in operation since 2002, was used throughout the research. The sewage came from the Residential Complex of the University of São Paulo (CRUSP) and received primary decanting before entering the pilot plant. Based on the respective percentage of $9.46 \%$ and $4.11 \%$ in terms of BOD (Bocchiglieri, 2005) of leachate applied to the sewage treated in the Barueri and Suzano STP, located in the metropolitan region of São Paulo, three experimental phases were performed varying the BOD load percentage applied to the process in $5 \%, 10 \%$ and $20 \%$ of the full load. This was done by varying the leachate input and by maintaining all the other conditions constant. The pilot units operated by removing the excess activated sludge in order to result in a 9-day old sludge global and, discounting the fraction of anoxic chamber, 6-day old sludge aerobic, based only on the concentration of suspended biomass (VSS). From the initial sewage characterization, a feed rate of $1.9 \mathrm{~m}^{3} \cdot \mathrm{d}^{-1}$ for the LAC pilot and $1.7 \mathrm{~m}^{3} \cdot \mathrm{d}^{-1}$ for the LAI pilot was established, corresponding to a food/ microorganism $(\mathrm{F} / \mathrm{M})$ ratio of $0.2 \mathrm{kgBOD} . \mathrm{kgVSS}^{-1} . \mathrm{d}^{-1}$ and an HRT of $0.48 \mathrm{~d}$. Both the decanted sewage and the landfill leachate, as well as the effluents produced by the processes, were characterized twice a week by determining the variables: total and soluble BOD, total and soluble COD, TKN, N-NH ${ }_{4}^{+}, \mathrm{N}_{-} \mathrm{NO}_{2}^{-}, \mathrm{N}_{-} \mathrm{NO}_{3}^{-}$ and Total Alkalinity. The sludge from the reactor was monitored by sensors and was characterized in terms of Total, Fixed and Volatile Suspended Solids. All the analytical methodologies followed the $21^{\text {st }}$ edition of the Standard Methods for Examination of Water and Wastewater, published by APHA / AWWA / WEF. To determine the attached biomass concentrations in the LAI pilot, 35 biomedia units occupying a volume of 40 $\mathrm{mL}$ were initially separated in a Falcon tube. Then, all the biomass was released by scraping with a toothbrush. Next, the mass of solids was determined by gravimetric analysis. After that, to obtain the concentration in terms of $\mathrm{mg} . \mathrm{L}^{-1}$, the mass was divided by the volume of the biomedia $(40 \mathrm{~mL})$, and to obtain the concentration in terms of $\mathrm{g} \cdot \mathrm{m}^{2}$, the mass was divided by the area of biomedia related to these $40 \mathrm{~mL}\left(0.012 \mathrm{~m}^{2}\right)$. Aiming to evaluate the kinetic behavior of the processes at each phase of the experiment, respirometric tests were performed with the sludge from both aerations tanks. For this, the experimental research employed an openended and semi-continuous Beluga S32c device, developed in the Department of Electrical Engineering of UFCG - Federal University of Campina Grande (Catunda et al., 1996). Table 1 presents the equations used for determining the kinetic coefficients concerning the growth of autotrophic bacteria.

To determine the constant of half-saturation $\left(\mathrm{K}_{\mathrm{n}}\right)$, Monod kinetics was considered; through respirograms, when $\mu=1 / 2 . \mu_{\text {máx }}$ or OUR $n=1 / 2$ OUR $_{\text {máx, }}$ the ratio between the area equivalent to the concentration of residual substrate (ammonia or nitrite) and its stoichiometric

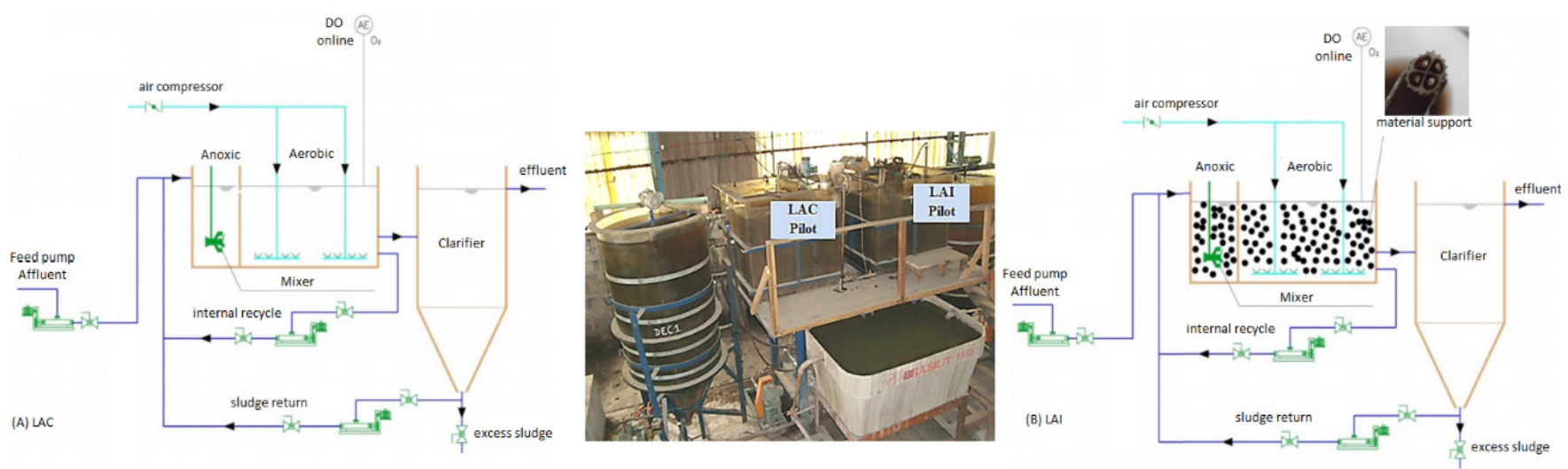

Figure 1. Schematic description of the Pilot Units (not in scale). (A) LAC (conventional activated sludge) and (B) LAI (Integrated Fixed-film Activated Sludge System). 
Table 1. Equations for determining the kinetic coefficients of nitrifying bacteria.

\begin{tabular}{cc}
\hline $\begin{array}{c}\text { Equations } \\
\text { (Van Haandel and Marais, 1999) }\end{array}$ & Eqs. \\
\hline OUR $_{\mathrm{n}}=\mathrm{OUR}_{\max }-\mathrm{OUR}_{\min }$ & \\
$\mathrm{r}_{\mathrm{n}}=\frac{\mathrm{OUR}_{\mathrm{n}}}{4,57} * 24$ & \\
$\mathrm{~N}_{\mathrm{l}}=\frac{0,1 * \mathrm{X}_{\mathrm{v}} * \mathrm{~V}_{\mathrm{r}}}{\mathrm{R}_{\mathrm{s}} * \mathrm{Q}_{\mathrm{inf}}}$ & \\
$\mathrm{N}_{\mathrm{c}}=\mathrm{TKN}_{\mathrm{i}}-\mathrm{TKN}_{\mathrm{e}}-\mathrm{N}_{\mathrm{l}}$ & \\
$\mathrm{X}_{\mathrm{n}}=\frac{\mathrm{Y}_{\mathrm{n}} * \mathrm{~N}_{\mathrm{c}} * \mathrm{R}_{\mathrm{s}}}{\left(1+\mathrm{b}_{\mathrm{n}} * \mathrm{R}_{\mathrm{s}}\right) * \mathrm{R}_{\mathrm{h}}}$ \\
$\mu_{\max }=\frac{\mathrm{Y}_{\mathrm{n}} * \mathrm{r}_{\mathrm{n}}}{\mathrm{X}_{\mathrm{n}}}$
\end{tabular}

where: OUR $\mathrm{n}_{\mathrm{n}}$ - oxygen uptake rate $\left(\mathrm{mgO}_{2} \cdot \mathrm{L}^{-1} \cdot \mathrm{h}^{-1}\right) ; \mathrm{r}_{\mathrm{n}}$ - specific speed of substrate utilization (mgN.mgX $\left.{ }^{-1} \cdot \mathrm{d}^{-1}\right) ; \mathrm{N}_{1}$ - nitrogen concentration in excess sludge $\left(\mathrm{mgN} . \mathrm{L}^{-1}\right) ; \mathrm{V}_{\mathrm{r}}$ - reactor volume $(\mathrm{L}) ; \mathrm{X}_{\mathrm{y}}-\mathrm{VSS}$ concentration in the aeration tank $\left(\mathrm{mg}^{\mathrm{L}} \mathrm{L}^{-1}\right) ; \mathrm{R}_{\mathrm{s}}$ - sludge age $(\mathrm{d}) ; \mathrm{Q}_{\mathrm{inf}}$ -

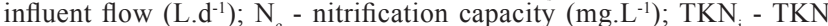
concentration in the influent $\left(\mathrm{mg} . \mathrm{L}^{-1}\right) ; \mathrm{TKN}_{\mathrm{e}}-\mathrm{TKN}$ concentration in the effluent $\left(\mathrm{mg} . \mathrm{L}^{-1}\right) ; \mathrm{X}_{\mathrm{n}}$ - concentration of active nitrifying organisms in the volatile biomass (mgVSS.L $\left.{ }^{-1}\right) ; \mathrm{R}_{\mathrm{b}}$ - hydraulic retention time $\left(\mathrm{d}^{-1}\right)$; $Y_{n}$ - coefficient of cell synthesis for nitrifying bacteria (adopted: 0.1 ) $\mathrm{b}_{\mathrm{n}}{ }^{\mathrm{n}}$ - decay constant of the nitrifying organisms (adopted: $0.04^{*} 1.03^{(\mathrm{T}-20)}$ ); $\mu_{\max }$ - maximum specific growth rate for nitrifying bacteria $\left(\mathrm{d}^{-1}\right)$.

coefficient of oxygen is calculates as 4.57 for ammonia and 1.14 for nitrite.

\section{RESULTS AND DISCUSSION}

\section{Characterization of the Influent and Application Rates}

The characterization of the decanted sewage provided a mean composition in terms of BOD of 210, 200 and $238 \mathrm{mgO}_{2} \cdot \mathrm{L}^{-1}$ and $\mathrm{COD}$ of 493,435 and 441 $\mathrm{mgO}_{2} \cdot \mathrm{L}^{-1}$, in the $1^{\text {st }}, 2^{\text {nd }}$ and $3^{\text {rd }}$ phases, respectively. In relation to the nitrogenous variables, mean values were obtained for each phase of 81,85 and 65 $\operatorname{mgTKN} . \mathrm{L}^{-1}$ and 65,74 and $51 \mathrm{mgN}-\mathrm{NH}_{4}^{+} \cdot \mathrm{L}^{-1}$ in the $1^{\text {st }}$, $2^{\text {nd }}$ and $3^{\text {rd }}$ phases, respectively. Observing these four variables, it can be stated that the decanted sewage remained relatively stable over the three experimental stages, possibly because the raw sewage discharge line does not receive contributions from rainwater or infiltration. Comparing the average results with typical literature values, both BOD and COD are verified to be compatible with average sewage values, whereas the values of TKN and $\mathrm{NH}_{4}^{+}$are similar to those of concentrated sewage. This peculiar composition is very likely due to the contribution of sewage produced by a restaurant and the presence of toilets providing a greater volume of urine, thus higher values for nitrogen compounds. In relation to the leachate used in each phase of the study, mean BOD values of 1369 , 1170 and $2042 \mathrm{mgO}_{2} \cdot \mathrm{L}^{-1}$ were achieved. The COD values were 3982,3845 and $4551 \mathrm{mgO}_{2} \cdot \mathrm{L}^{-1}$; for the nitrogen series, in terms of TKN the values were 2331, 2036 and 2055 mgTKN.L ${ }^{-1}$ and 2075, 1826 and 1860 $\mathrm{mgNH}_{4}^{+} \cdot \mathrm{L}^{-1}$ in the $1^{\text {st }}, 2^{\text {nd }}$ and $3^{\text {rd }}$ phases, respectively. The results obtained for the BOD and COD variables classify it as leachate from the intermediate landfill, with a $\mathrm{BOD} / \mathrm{COD}$ ratio between 0.3 and 0.4 , while the results for TKN and $\mathrm{NH}_{4}^{+}$are typical of new landfill leachate. Considering the leachate input variation in the composition of the flow applied to the pilot units for each phase, Table 2 lists the calculated average values for the characterization of the real influent throughout the research, obtained by mass balance.

Consistent values regarding the $\mathrm{BOD}$ concentration were observed throughout the study. However, there was an increase in the COD concentration due to the contribution of leachate, demonstrating that this indicator offers greater sensitivity for evaluating the increase of recalcitrant organic matter in the leachate. Concerning nitrogenous compounds, a gradual increase is observed from one phase to another as a function of the high concentrations in the leachate. The same occurred with the alkalinity concentration. The organic volumetric load (OVL) and nitrogen volumetric load (NVL) were applied to the processes. Typical results for the biological processes of activated sludge were obtained, 0.48 to $0.72 \mathrm{kgBOD} \cdot \mathrm{m}^{3} \cdot \mathrm{d}^{-1}$ and 0.35 to $0.89 \mathrm{kgN} \cdot \mathrm{m}^{3} \cdot \mathrm{d}^{-1}$.

\section{Characterization of Suspended and Attached Biomass}

It was possible to work with desirable values of VSS in the sludge aeration tank due to the operating conditions imposed on the process in most of the study (2000-5000 mg.L.-1, according to Van Haandel and Marais, 1999). Table 3 presents the descriptive statistics of the VSS results in the sludge aeration tank for both pilot units.

Concerning the sludge from the return line, average values between 3000-6000 mgVSS.L $\mathrm{L}^{-1}$ were obtained in both pilot units. This shows that the leachate load introduced did not affect the formation

Table 2. Influent characterization (sewage + leachate).

\begin{tabular}{|c|c|c|c|c|c|c|c|c|c|}
\hline \multirow{2}{*}{ Variable } & \multicolumn{3}{|c|}{$1^{\text {st }}$ phase (5\% leachate) } & \multicolumn{3}{|c|}{$2^{\text {nd }}$ phase (10\% leachate) } & \multicolumn{3}{|c|}{$3^{\text {rd }}$ phase (20\% leachate) } \\
\hline & $\mathbf{n}$ & Avg & SD & $\mathbf{n}$ & Avg & SD & $\mathbf{n}$ & Avg & SD \\
\hline COD total $\left(\mathrm{mgO}_{2} \cdot \mathrm{L}^{-1}\right)$ & 19 & 522 & 93 & 8 & 531 & 51 & 20 & 614 & 95 \\
\hline BOD total $\left(\mathrm{mgO}_{2} \cdot \mathrm{L}^{-1}\right)$ & 19 & 220 & 22 & 8 & 216 & 6 & 20 & 286 & 51 \\
\hline $\operatorname{COT}\left(\mathrm{mgC} . \mathrm{L}^{-1}\right)$ & 19 & 59 & 9 & 8 & 71 & 11 & 20 & 84 & 25 \\
\hline TKN (mgN.L-1) & 19 & 107 & 18 & 8 & 157 & 17 & 20 & 214 & 48 \\
\hline $\mathrm{NH}_{4}^{+}\left(\mathrm{mgN} . \mathrm{L}^{-1}\right)$ & 19 & 82 & 5 & 8 & 108 & 11 & 20 & 125 & 28 \\
\hline Alkalinity (mgCaCO $\left.3 . \mathrm{L}^{-1}\right)$ & 19 & 228 & 50 & 8 & 369 & 26 & 20 & 568 & 154 \\
\hline
\end{tabular}


Table 3. Descriptive Statistics of the Results of VSS Sludge Aeration Tank.

\begin{tabular}{|c|c|c|c|c|c|c|}
\hline & \multicolumn{2}{|c|}{$1^{\text {st }}$ phase (5\% leachate) } & \multicolumn{2}{|c|}{$2^{\text {nd }}$ phase $(10 \%$ leachate) } & \multicolumn{2}{|c|}{$3^{\text {rd }}$ phase (20\% leachate) } \\
\hline & LAC & LAI & LAC & LAI & LAC & LAI \\
\hline & \multicolumn{6}{|c|}{$\left(\mathbf{m g . L}^{-1}\right)$} \\
\hline Num. Data & 19 & 19 & 8 & 8 & 20 & 20 \\
\hline Median & 3120 & 2450 & 3065 & 2090 & 3570 & 3235 \\
\hline Average & 2954 & 2319 & 2953 & 2225 & 3610 & 3099 \\
\hline Minimum & 1230 & 1390 & 2290 & 1650 & 2520 & 1850 \\
\hline Maximum & 4020 & 3410 & 3390 & 3310 & 4820 & 4680 \\
\hline Coef. Var. & 0,26 & 0,28 & 0,13 & 0,24 & 0,19 & 0,24 \\
\hline Standard Dev. & 762 & 649 & 377 & 534 & 687 & 752 \\
\hline
\end{tabular}

of the suspended biomass in any experimental phase. Using the methodology developed for quantifying the attached biomass and considering the specific surface area of the Kaldnes ${ }^{\circledR}$ holders of type K1 $\left(300 \mathrm{~m}^{2} \cdot \mathrm{m}^{-3}\right)$, VSS values of $12.9,7.2$ and $12.6 \mathrm{gVSS} . \mathrm{m}^{-2}$ of biofilm, respectively, were obtained throughout the study in the three experimental phases. These are within the range found in the literature: 2 to $44 \mathrm{gVSS} \cdot \mathrm{m}^{-2}$ (Fujji, 2011; Minegatti, 2008; Luostarinen et al., 2006; Andreottola et al., 2003).

Figure 2 illustrates the historical series of VSS concentrations in both suspended and attached biomass.

According to Figure 2, similar behavior was found in the suspended and attached VSS concentrations throughout the study, with the exception of the $2^{\text {nd }}$ phase, in which an increase in the suspended VSS values occurred while the attached VSS values decreased. We can hypothesize that, in this phase, operational problems may have caused a more intense detachment of the biofilm. The VSS contribution from the attached biomass resulted in an increase of $75 \%, 43 \%$ and $55 \%$, respectively, for each phase of the study, concerning the suspended biomass. Note that the biomedia had a specific surface area of 300 $\mathrm{m}^{2} / \mathrm{m}^{3}$, and there is currently available material with values two or three times as high; furthermore, the filling percentage may be higher, too. Thus, the ratio between the attached and suspended biomass may be so high as to allow effective operation as a MBBR, that is, without sludge recirculation. Regarding

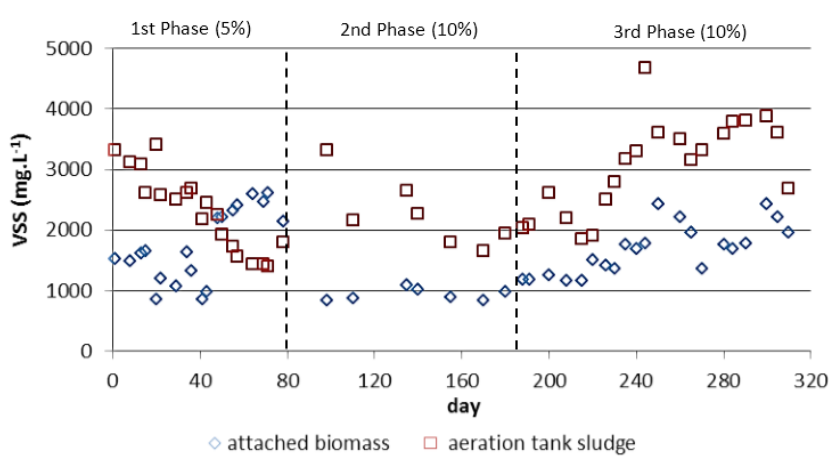

Figure 2. Historical VSS series referring to suspended and attached biomass. the composition in terms of nitrogen (TKN) of the attached biomass, the values obtained were very close to those typically observed in biomass in suspension in activated sludge systems, i.e., approximately $10 \%$ of the VSS mass. The evaluation of hybrid systems, such as the IFAS process, must comprehend the individual participation of the contributions allocated to each fraction of biomass, attached or in suspension, in the treatment process. To estimate the substrate consumption by the biofilm area, the values suggested by WEF (2008) were used. Their development was based on the kinetic model of the process. Thus, by linear interpolation, for 6 day old aerobic sludge, the fractions applied to the attached biomass was 35\% of Ammoniacal Nitrogen. Considering this fraction, the application rates were calculated for the area of the Ammoniacal Nitrogen biofilm. Figure 3 makes it possible to conclude that, during the first phase of the study, the nitrogen surface application rates per area of biofilm initially presented a negative oscillation. Then the rates recovered and increased as the leachate input percentage increased.

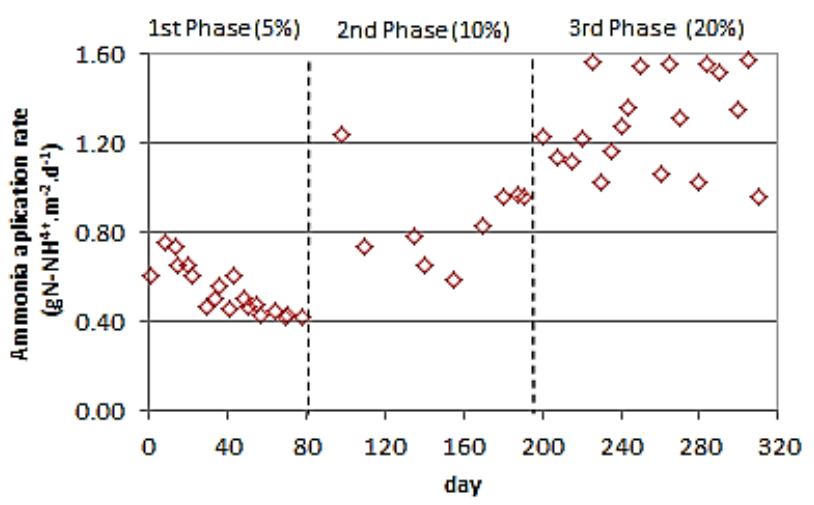

Figure 3. Application rates of ammoniacal nitrogen by biofilm area.

\section{Removal of Nitrogenous Compounds}

Regarding the removal of nitrogen compounds, the systems can be started to be kept under stable operation in the three stages of the research. Figure 4 illustrates the historical series concerning ammoniacal and TKN concentrations measured for the influent (sewage + leachate) applied to the pilot units. 


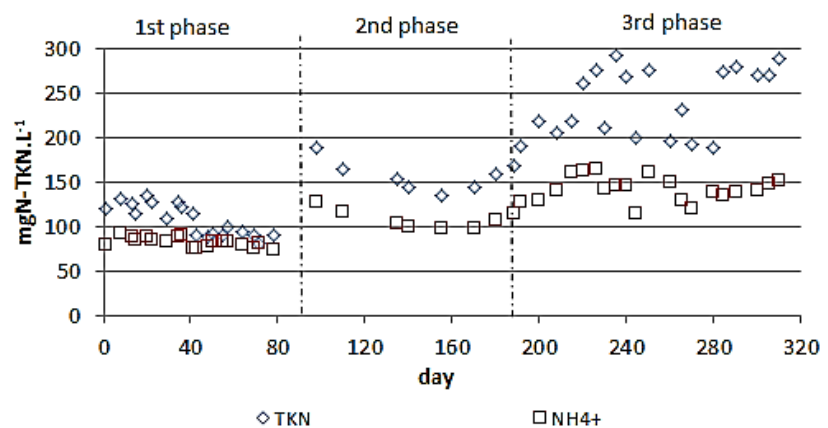

Figure 4. Historical series of the variables $\mathrm{NH}_{4}^{+}$e TKN - Influent.

The concentration obtained in the influent for these variables was strongly influenced by the progressive contribution of leachate to each phase of the research, and an increase of the concentration along the historical series, reaching values considerably above those commonly found for concentrated domestic sewage (Metcalf and Eddy, 2014). In relation to the efficiency of the processes, it was possible to obtain rates of approximately $90 \% \mathrm{TKN}$ and $\mathrm{NH}_{4}^{+}$conversion in the first two phases. In the $3^{\text {rd }}$ phase, rates on the order of $80 \%$ were obtained for the LAI pilot, while the LAC pilot presented approximately $70 \%$ for TKN conversion during the three operational phases, and $74 \%$ for $\mathrm{NH}_{4}^{+}$only in the $1^{\text {st }}$ phase, with a significant drop in yield in the following two phases, in which values from $50 \%$ to $60 \%$ were observed. Using BoxWhiskers diagrams, Figure 5 shows the TKN and $\mathrm{NH}_{4}^{+}$concentrations measured in the effluent from both pilot units.

In general, the LAC pilot effluent results performed below the expected in relation to nitrogen compound removal, especially in the last phase. The LAI pilot presented relative stability in the first two phases, with average values of ammonia nitrogen and TKN and poorer results in phase 3 , when the leachate load was the greatest during the study. Regardless of the low yield observed, both pilots were able to reduce TKN concentrations more than those commonly found in concentrated sanitary sewage, reaching concentrations

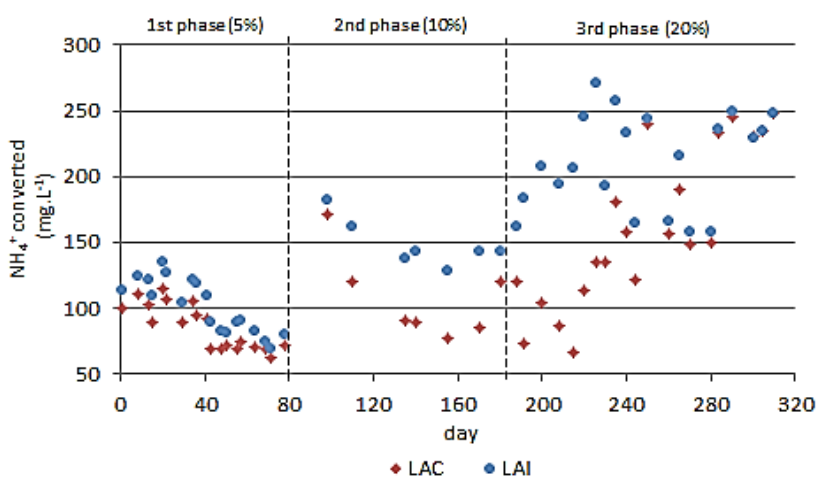

Figure 6. Concentration of ammonia converted along the study.

(A) LAC Pilot Effluent - TKN and $\mathrm{NH}_{4}^{+}$, respectively.
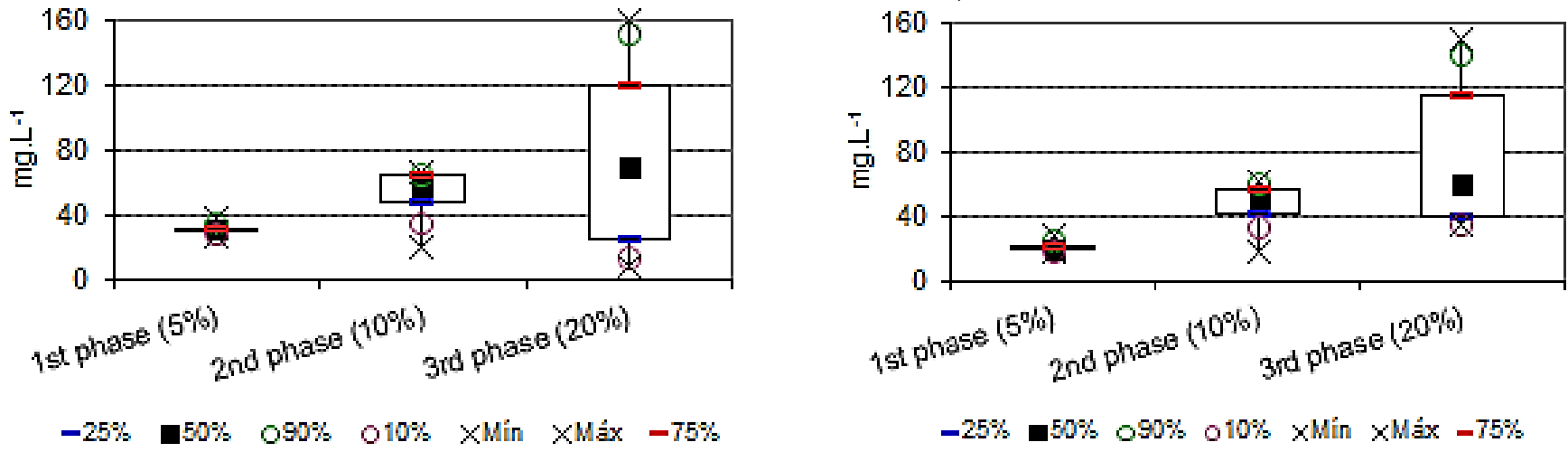

(B) LAI Pilot Effluent $-\mathrm{TKN}$ and $\mathrm{NH}_{4}^{+}$, respectively.
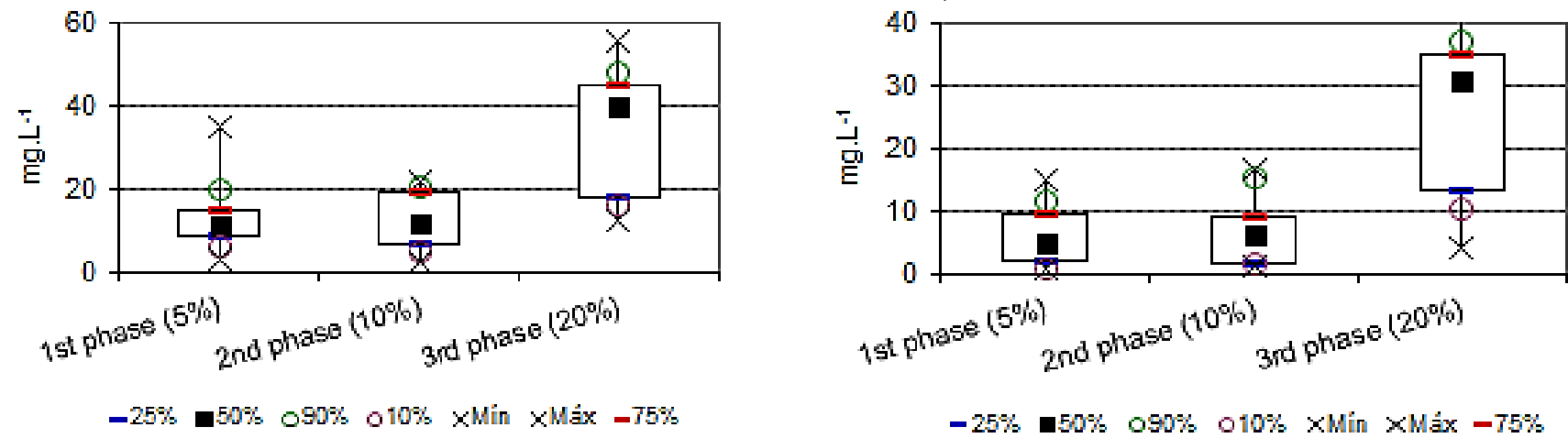

Figure 5. Box-Whisker diagram of concentrations of $\mathrm{TKN}$ and $\mathrm{NH}_{4}^{+}$measured in effluents (A) LAC and (B) LAI. 
of approximately $250 \mathrm{mg} \cdot \mathrm{L}^{-1}$ of converted ammonia. Figure 6 presents the results of the historical series of $\mathrm{NH}_{4}^{+}$concentration converted in both processes, obtained by the difference between the concentration of TKN flux and $\mathrm{NH}_{4}^{+}$effluent.

In general, it can be concluded that releasing progressive loads of leachate mixed with the sewage did not inhibit the treatment process in either system. The pilot unit that operated as a hybrid system of activated sludge with mobile bio-media was shown to be more stable and promising in the reduction of TKN. However, the LAI pilot results in the third phase of the study, in which the effluent presented average values of $30 \mathrm{mgN}-\mathrm{NH}_{4}^{+} \cdot \mathrm{L}^{-1}$, infers the possibility that the leachate load of $20 \%$ may have influenced the performance decrease of this system, therefore demonstrating that this condition may be limiting to the process.

\section{Nitrification and Denitrification}

Figure 7 shows the nitrification rates applied to each pilot throughout the study. The results show that the LAI pilot presented greater stability in the nitrification phenomenon, verified by the linear behavior allied

(A) LAC Pilot

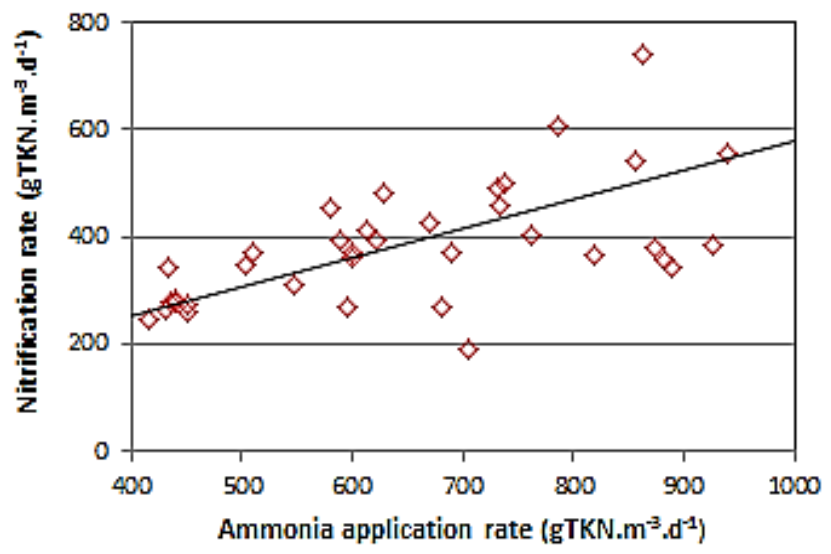

Figure 7. Nitrification rates obtained during the Study. (A) LAC and (B) LAI.

(A) LAC Pilot

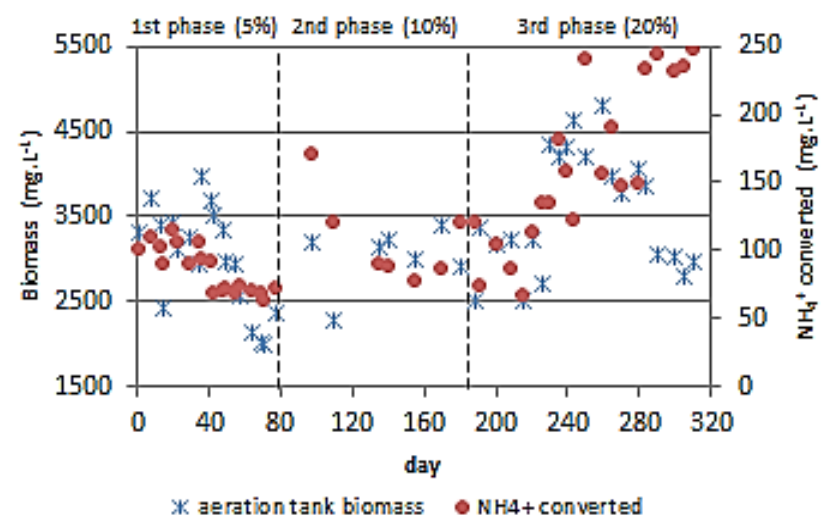

to the good adhesion of all the points, generating a slope. This indicated that there was no reduction in the nitrification rate in any phase of the study, even with the proportional increase of leachate in the composition of the applied loads. This cannot be observed in the LAC pilot, given the dispersion pattern of the points, which, in theory, is confirmed by the poor results already presented regarding TKN and ammoniacal nitrogen removal. Another important aspect is that the nitrification rates applied to the LAI pilot during the whole research reached greater numbers than those proposed by Copithorn et al. (2000), from 300 to 400 $\mathrm{gN}-\mathrm{NH}_{4}^{+} \cdot \mathrm{m}^{-3} \cdot \mathrm{d}^{-1}$, for MBBR-type systems.

Figure 8 shows the correlation between the ammonia conversion and the biomass concentration (VSS) in the aeration tanks of both processes, as a function of the indirect influence that the VSS concentration in the aeration tank exerts on the population of nitrifying bacteria.

According to Figure 8, a correlation is observed between the VSS concentration in the aeration tank with the increase of the ammonia conversion rate in both processes. In the LAI pilot unit, there was also an increase in the VSS from the adhered biomass, with a

(B) LAI Pilot

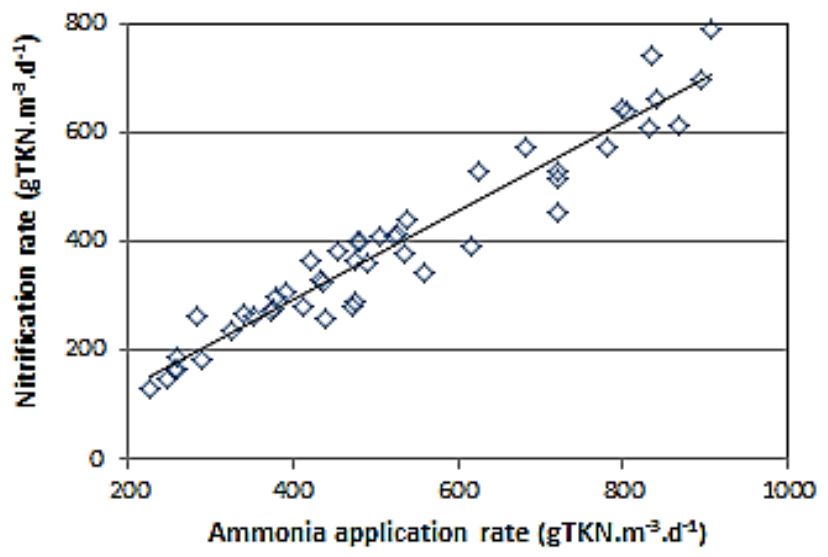

(B) LAI Pilot

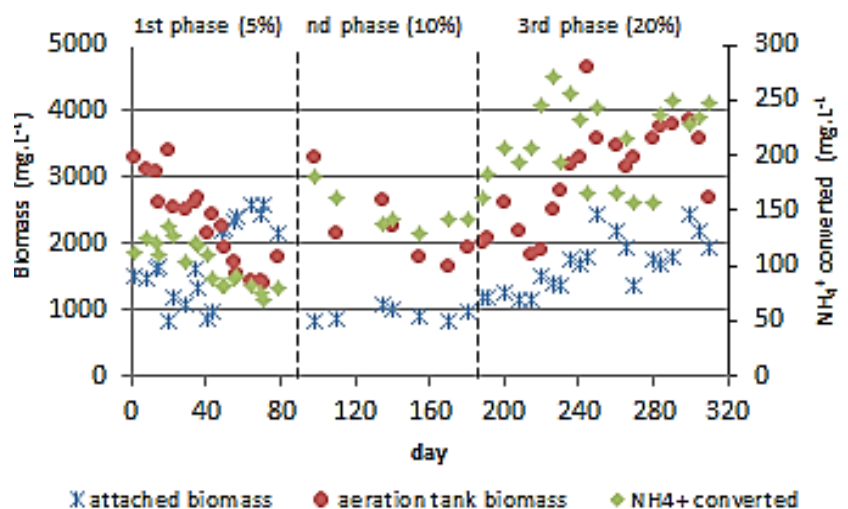

Figure 8. Correlation between ammonia converted and VSS present in the aeration tanks. (A) LAC and (B) LAI. 
quantitative contribution. Regarding the contribution of the adhered biomass to the LAI pilot unit in the nitrification phenomenon, after recalculating the nitrification rates and the ammonia surface load, following the previously mentioned assumptions regarding the fraction applied to the adhered biomass in terms of ammoniacal nitrogen (WEF MOP n. 8, 2009), the results shown in Figure 9 were obtained.

The observed nitrification results from the pilot system are similar to those presented by Rusten et al. (1995), indicating good removal efficiency with 8 gCOD. $\mathrm{m}^{2} \cdot \mathrm{d}^{-1} \mathrm{COD}$ loads. Concerning the denitrification phenomenon, the nitrite and nitrate values obtained in the LAC pilot effluent remained relatively stable, presenting sporadic peaks throughout the experiment. The $1^{\text {st }}$ phase of the LAI pilot presented consistent values and was followed by an increase which lasted up to the middle of the $3^{\text {rd }}$ phase. In general, the nitrate variable presented peaks with concentrations higher than the desired $10 \mathrm{mg} . \mathrm{L}^{-1}$ throughout most of the experiment. Figure 10 displays the results of nitrate and nitrite concentrations obtained throughout the study.

Nitrate consumption was observed in the denitrification phenomenon during the entire experiment, in very similar concentrations to the theoretically generated values. This indicated that,

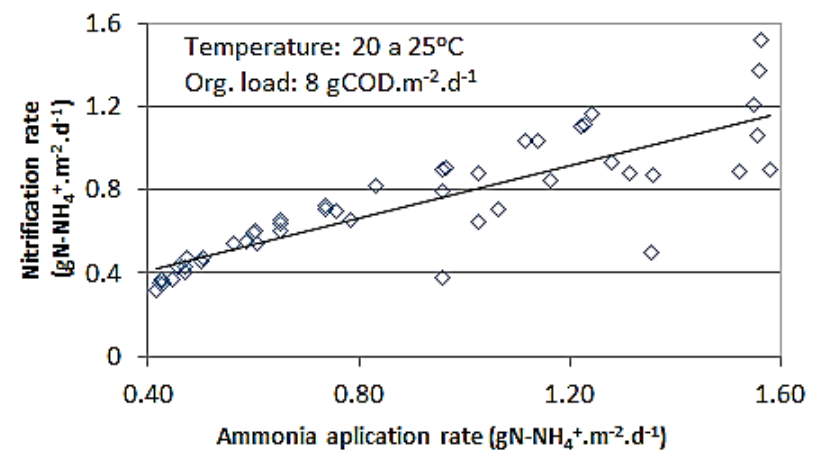

Figure 9. Nitrification rate by biofilm area.

(A) LAC Pilot

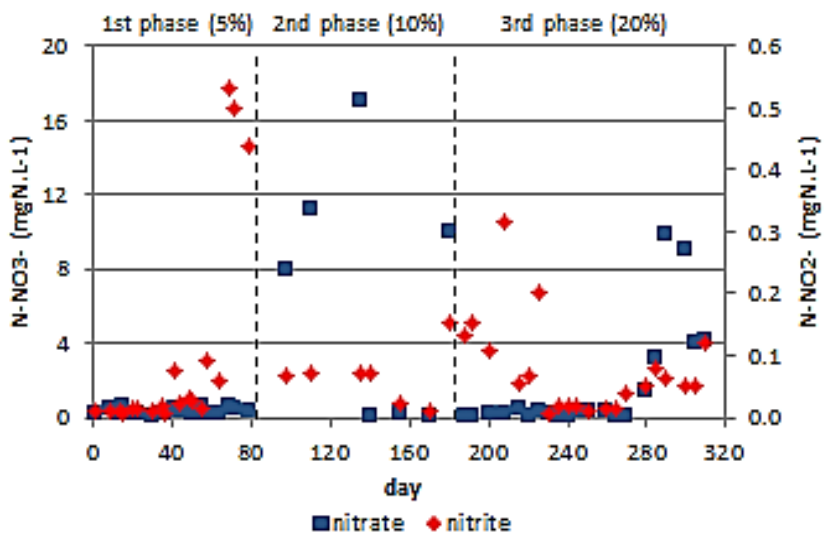

overall, the introduction of leachate did not compromise this stage of the treatment. Figure 11 displays the comparative results between the theoretical nitrate concentration, as a function of the amount of tributary TKN that can be converted into nitrate, and the concentration of nitrate effectively denitrified in both processes.

In both processes, the amounts of denitrified nitrate were very similar to the theoretically generated nitrate

(A) LAC Pilot

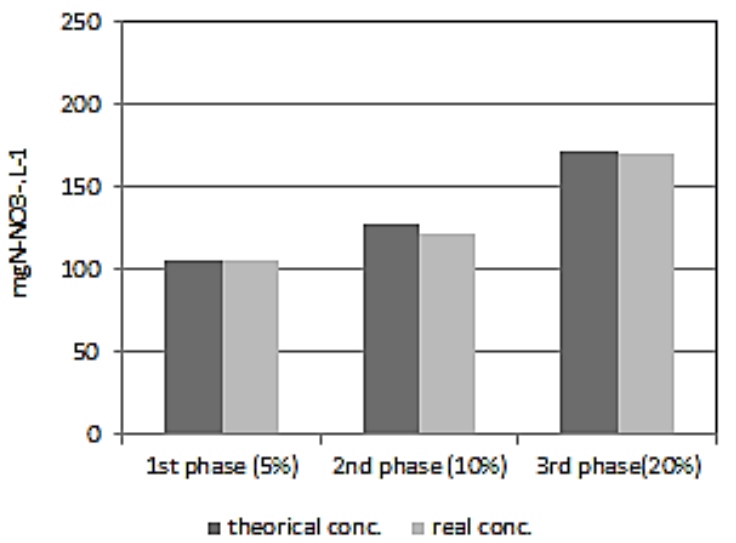

(B) LAI Pilot

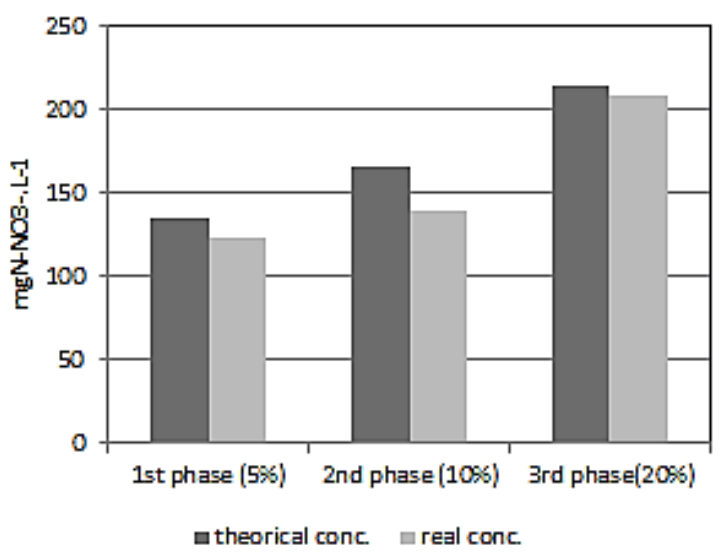

Figure 11. Denitrification Capacity. (A) LAC and (B) LAI.

(B) LAI Pilot

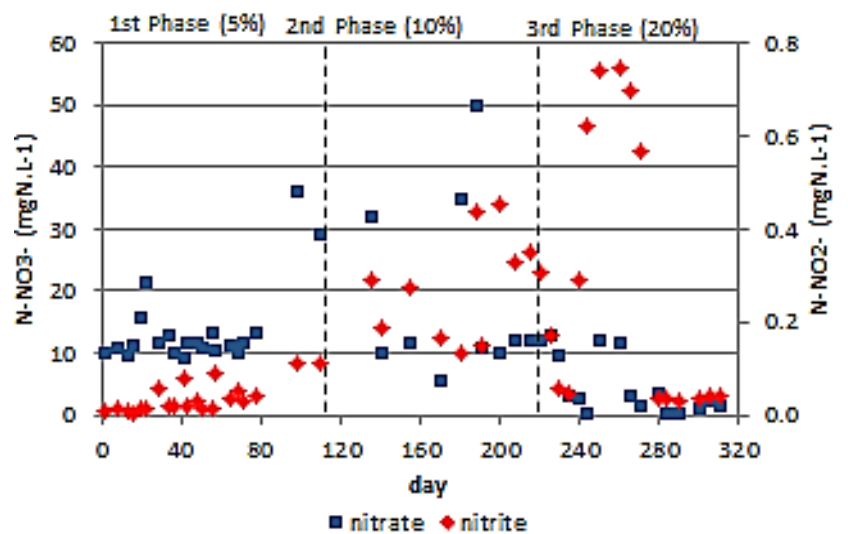

Figure 10. Historical Series of the $\mathrm{NO}_{3}{ }^{-}$e $\mathrm{NO}_{2}{ }^{-}$concentration. (A) LAC and (B) LAI. 
concentration, indicating that the denitrification stage occurred satisfactorily in all the phases of the study. Note, however, that in the LAI process the denitrified concentration was higher than that obtained in the LAC process because, in the latter, nitrification did not entirely occur, as discussed previously.

\section{Respirometric Tests}

In order to evaluate the metabolic behavior of heterotrophic bacteria active in the process, tests were carried out with suspended biomass from the LAC pilot. For the LAI pilot tests were performed with total biomass (attached biomass + suspended biomass) and suspended biomass. Table 4 informs the average values of the kinetic constants of growth and utilization of nitrogen material for nitrifying bacteria.

According to Table 4, the values of the maximum growth constant of the nitrite bacteria $\left(\mu_{\max }\right)$ for the LAC pilot remained stable over the three phases of the research, while for the LAI pilot, a progressive decrease in suspended biomass and in total biomass (suspension + adhered) was observed. A negative oscillation occurred in the $2^{\text {nd }}$ phase. In general, regardless of possible changes in $\mu_{\max }$ values, there was no similar damage to the removal efficiency of the nitrogen compounds. This result confirms what is found in the literature regarding nitrification in activated sludge processes, where $\mu_{\max }$ values range from 0.1 to 1.0 $\mathrm{d}^{-1}$, with an average of $0.4 \mathrm{~d}^{-1}$ and $\mathrm{Kn}$ range between 0.0 and $2.0 \mathrm{mg} . \mathrm{L}^{-1}$, with an average of $0.5 \mathrm{mg} . \mathrm{L}$ 1 (Van Haandel \& Marais, 1999; Fujji et al., 2013; Abreu et al, 2017). Figure 12 shows the correlation between the $\mu_{\max }$ constants for the suspended biomass of the LAC pilot unit and the total biomass of the LAI pilot, with the efficiency of TKN removal. The halfsaturation constant of Monod $(\mathrm{Kn})$ and maximum rate of ammonia use $\left(r_{n \max }\right)$ had a similar behavior to that observed for the constant $\mu_{\max }$.

Due to operational problems, it was not possible to determine the kinetic constants of the nitrating bacteria in the $20 \%$ phase for the LAC process; low values were

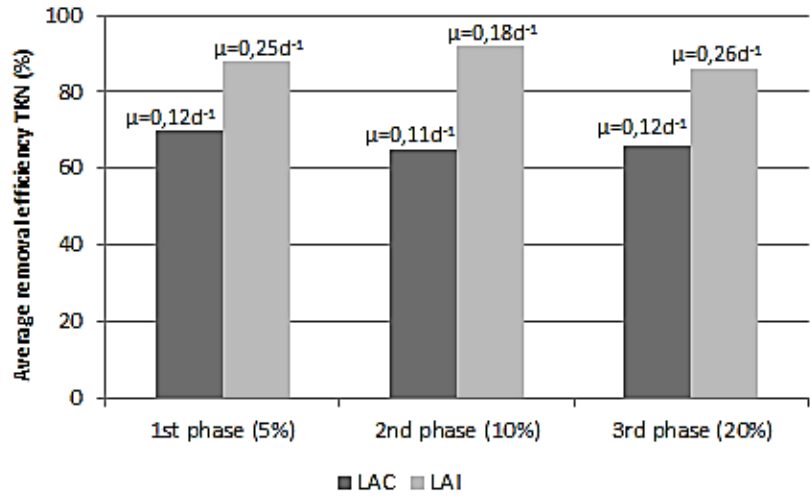

Figure 12. Correlation between TKN and $\mu_{\max }$ removal efficiency.

thus obtained for the suspended biomass of the LAI pilot unit. The numbers found for maximum growth rate $\left(\mu_{\mathrm{m}}\right)$ of the nitrating bacteria were very similar to those obtained for the nitrite bacteria, which presents a relative balance between the two populations. Table 5 shows the values found.

\section{CONCLUSION}

The results from the experimental investigation allow us to conclude that adding leachate loads to domestic sewage is a viable alternative for the appropriate stabilization of this type of wastewater, and that the precise operational control of the treatment plant is fundamental for effectively performing the process. Both the conventional activated sludge (LAC) and the IFAS (LAI) hybrid process were promising and stable in the presence of recalcitrant organic compounds from landfill leachate. The second model presented greater stability and operational robustness due to the adhered biomass. The percentage contribution of leachate to the composition of the tributary load provides greater clarity and comparative power of the possible impacts caused in treatment plants. In general, it was possible to receive up to $20 \%$ of the landfill leachate load in both systems without harming the removal of nitrogenous

Table 4. Average Values of the Kinetic Coefficients of Bacteria Nitrifying.

\begin{tabular}{|c|c|c|c|c|c|c|c|c|c|}
\hline \multirow[b]{2}{*}{$\begin{array}{c}\text { Phases } \\
(\%)\end{array}$} & \multicolumn{3}{|c|}{ LAC } & \multicolumn{3}{|c|}{ LAI - Suspended Biomass } & \multicolumn{3}{|c|}{ LAI - Total Biomass } \\
\hline & $\underset{d^{-1}}{\mu_{\max }}$ & $\begin{array}{c}\mathrm{r}_{\max } \\
\mathrm{mgNH}_{4}^{+} \cdot \mathrm{mgX}_{\mathrm{a} \cdot \mathrm{d}^{-1}}\end{array}$ & $\underset{\mathbf{m g} . \mathrm{L}^{-1}}{\mathrm{~K}_{\mathbf{n}}}$ & $\begin{array}{c}\mu_{\max } \\
d^{-1}\end{array}$ & $\begin{array}{c}\mathbf{r}_{\max } \\
\mathrm{mgNH}_{4}^{+} \cdot \mathrm{mgX}_{\mathrm{a}} \cdot \mathrm{d}^{-1}\end{array}$ & $\begin{array}{c}K_{n} \\
\text { mg. } L^{-1}\end{array}$ & $\begin{array}{c}\mu_{\max } \\
d^{-1}\end{array}$ & $\begin{array}{c}\mathbf{r}_{\max } \\
\mathrm{mgNH}_{4}^{+} \cdot \mathrm{mgX}_{\mathrm{a}} \cdot \mathrm{d}^{-1}\end{array}$ & $\begin{array}{c}\mathbf{K}_{\mathbf{n}} \\
\mathrm{mg} \cdot \mathrm{L}^{-1}\end{array}$ \\
\hline 5 & 0.12 & 9.0 & 1.3 & 0.19 & 9.5 & 1.1 & 0.25 & 10 & 1.3 \\
\hline 10 & 0.11 & 7.7 & 0.5 & 0.14 & 9.8 & 0.5 & 0.18 & 10.5 & 1.1 \\
\hline 20 & 0.12 & 7.7 & 0.7 & 0.12 & 9.2 & 1.0 & 0.26 & 10.4 & 1.4 \\
\hline
\end{tabular}

Table 5. Average values of the kinetic coefficients of nitrifying bacteria.

\begin{tabular}{|c|c|c|c|c|c|c|}
\hline \multirow[b]{2}{*}{$\begin{array}{c}\text { Phases } \\
(\%)\end{array}$} & \multicolumn{3}{|c|}{ LAC Pilot } & \multicolumn{3}{|c|}{ LAI Pilot - Total Biomass } \\
\hline & $\begin{array}{l}\mu_{m} \\
\mathbf{d}^{-1}\end{array}$ & $\begin{array}{c}K_{n} \\
\text { mg. }^{-1}\end{array}$ & $\begin{array}{c}r_{\mathrm{n} \max } \\
\mathrm{mgNH}_{4}^{+} \cdot \mathrm{mgX}_{\mathrm{a} \cdot} \cdot \mathrm{d}^{-1}\end{array}$ & $\begin{array}{l}\mu_{m} \\
d^{-1}\end{array}$ & $\begin{array}{c}K_{n} \\
m g . L^{-1}\end{array}$ & $\begin{array}{c}\mathbf{r}_{\mathrm{n} \max } \\
\mathrm{mgNH}_{4}^{+} \cdot \mathrm{mgX}_{\mathrm{a}} \cdot \mathrm{d}^{-1}\end{array}$ \\
\hline 5 & 0.11 & 1.1 & 10.5 & 0.25 & 1.85 & 9.9 \\
\hline 10 & 0.16 & 1.0 & 17.5 & 0.22 & 2.11 & 10.2 \\
\hline 20 & - & - & - & 0.14 & 1.97 & 10.2 \\
\hline
\end{tabular}


matter. The kinetic coefficients for nitrifying bacteria obtained in the respirometric tests are consistent with those commonly found in the literature and, despite possible oscillations, did not show negative effects on the treatment efficiency, reinforcing the conclusion that the introduced leachate loading did not cause inhibition or significant changes in autotrophic metabolism.

\section{REFERENCES}

Abreu, A. F., Catunda, Y. S. C., Guimarães, P., van Haandel,A.UsodaRespirometria paraDeterminação Experimental da Cinética de Nitrificação. Anais do XXVII Congresso Interamericano de Engenharia Sanitária e Ambiental - ABES (2017).

Andreottola, G., Oliveira, E. L., Foladori, P., Dallago, L., Peterlini, R., Cadonna, M. Método Respirométrico para o Monitoramento de Processos Biológicos. Engenharia Sanitária e Ambiental, 10, 14 -23 (2005). https://doi.org/10.1590/S141341522005000100003

APHA/AWWA/WEF, Standard Methods for the Examination of Water and Wastewater, 21 a Edição, Washington DC (2005).

Bassin, J. P., Dezotti, M. Moving Bed Biofilm Reactor (MBBR). In: Advanced Biological Processes for Wastewater Treatment. Springer, Cham, p. 37-74 (2018). https://doi.org/10.1007/978-3-319-5883533

Bocchiglieri, M. M. A Influência do Recebimento de Chorume dos Aterros Sanitários da Região Metropolitana de São Paulo nas Estações de Tratamento de Esgotos do Sistema Integrado. Dissertação apresentada à Faculdade de Saúde Pública da USP. São Paulo (2005).

Boyle, W. C., Ham, R. K. Biological treatability of landfill leachate. Journal (Water Pollution Control Federation), p. 860-872 (1974).

Brennan, R. B., Clifford, E., Devroedt, C., Morrison, L., Healy, M. G. Treatment of landfill leachate in municipal wastewater treatment plants and impacts on effluent ammonium concentrations. Journal of Environmental Management, 188, 64-72 (2017). https://doi.org/10.1016/j.jenvman.2016.11.055

Campos, F. Influência do recebimento de lixiviado de aterro sanitário sobre o tratamento de esgoto em processo de lodo ativado e reator integrado de lodo ativado com biofilme em leito móvel (Doctoral dissertation, Universidade de São Paulo) (2014).

Campos, F., Bueno, R. F., Piveli, R. P. Influence of the receiving of leachate from sanitary landfill on the sewage treatment in process of activated sludge with mobile biomedia. Desalination and Water Treatment, 63, 69-77 (2017). https://doi. org/10.5004/dwt.2017.20182
Canziani, R., Emondi, V., Garavaglia, M., Malpei, F., Pasinetti, E., Buttiglieri, G. Effect of oxygen concentration on biological nitrification and microbial kinetics in a cross-flow membrane bioreactor (MBR) and moving-bed biofilm reactor (MBBR) treating old landfill leachate. Journal of Membrane Science, 286, 202-212 (2006). https:// doi.org/10.1016/j.memsci.2006.09.044

Çecen, F., Çakirolum, D. Impact of Landifill Leachate on the Co-Treatment of Domestic Wastewater. Biotechnology Letters, 23, 821-826 (2001). https:// doi.org/10.1023/A:1010317823529

Copithorn, D. S. R., Randal, C., Phago, R. J. D., Rusten, B. (2000). Investigation of Hybrid Systems for Enhanced Nutrient Control. Water Envarionment Research Foundaton (WERF).

Daigger, G. T., Boltz, J. P. Oxygen Transfer in Moving Bed Biofilm Reactor and Integrated Fixed Film Activated Sludge Processes. Water Environment Research, 90, 615-622 (2018). https://doi.org/10.2 175/106143017X15054988926596

Dezotti, M., Sant'anna Jr., G., Bassin, J. P. Processos Biológicos Avançados para Tratamento de Efluentes e Técnicas de Biologia Molecular para Estudo da Diversidade Microbiana. $1^{\mathrm{a}}$ Edição, Rio de Janeiro, Editora Interciências Ltda. (2011).

Diamadopoulos, E., Samaras, P., Dabou, X., Sakellaropoulos, G. P. Combined treatment of landfill leachate and domestic sewage in a sequencing batch reactor. Water Science and Technology, 36, 61-68 (1997). https://doi. org/10.2166/wst.1997.0483

Ehrig, H. J. Co-treatment in domestic sewage facilities. In: International Training Seminar: Management and Treatment of MSW Landfill Leachate. Cagliari: CISA, p. 1-10 (1998).

Fujii, F. Y. Análise Comparativa Entre o Processo de Lodo Ativado e o Reator de Biofilme de Leito Móvel na Remoção de Nitrogênio de Esgoto Sanitário. Dissertação apresentada à Escola Politécnica da Universidade de São Paulo, área de concentração: Engenharia Civil (2011).

Fujii, F. Y., Piveli, R. P., Campos, F., Bueno, R. F., Alem Sobrinho, P. Desempenho de reator integrado de lodo ativado com biofilme em leito móvel. Engenharia Sanitária e Ambiental, 18, 349-358 (2013). https://doi.org/10.1590/S141341522013000400007

Kalka, J. Landfill leachate toxicity removal in combined treatment with municipal wastewater. ScientificWorld Journal, 2012, 1-7 (2012). https:// doi.org/10.1100/2012/202897

Klimiuk, E., Kulikowska, D. The influence of hydraulic retention time and sludge age on the kinetics of nitrogen removal from leachate in SBR. Polish Journal of Environmental Studies, 15, 283-289 (2006). 
Luostarinen, S., Luste, S., Valentin, L., Rintala, J. Nitrogen removal from on-site treated anaerobic effluents using intermittently aerated moving bed biofilm reactors at low temperatures. Water Research, 40, 1607-1615 (2006). https://doi. org/10.1016/j.watres.2006.02.022

McBean, E., Bleiker, D. E., Farquhar, G. Landfill settlement and the impact on site capacity and refuse hydraulic conductivity. Waste Management \& Research, 13, 533-554 (1995). https://doi. org/10.1177/0734242X9501300604

Metcalf \& Eddy, Inc. Wastewater Engineering: Treatment and Reuse. 5.ed, Tchobanoglous, G., Burton, F. L., Stensel, H. D. (Editores), McGrawHill, Nova Yorque (2014).

Minegatti, D. V. O. Caracterização dos Parâmetros de Controle e Avaliação de Desempenho de um Reator Biológico com Leito Móvel (MBBR) (Doctoral dissertation, Dissertação de mestrado. Departamento de Engenharia Civil Universidade Federal do Rio de Janeiro, 91p) (2008).

Ødegaard, H., Rusten, B., Westrum, T. A New Moving Bed Biofilm Reactor - Applications and Results. Water Science Technology, 29, 157-165 (1994). https://doi.org/10.2166/wst.1994.0757

Sivic, A., Atanasova, N., Puig, S., Bulc, T. G. Ammonium removal in landfill leachate using SBR technology: dispersed versus attached biomass. Water Science and Technology, 77, 27-38 (2018). https://doi.org/10.2166/wst.2017.519 van Haandel, A. C., Marais, G. V. R. O Comportamento do Sistema de Lodo Ativado: Teoria e Aplicações para Projetos e Operações. Campina Grande: EPGRAF, 472 p. (1999).

Yuan, Q., Jia, H., Poveda, M. Study on the effect of landfill leachate on nutrientes removal from municipal wasterwater. Journal of Environmental Sciences, 43, 153-158 (2016). https://doi. org/10.1016/j.jes.2015.10.023

Ye, Z.-L., Xie, X., Dai, L., Wang, Z., Wu, W., Zhao, F., Xie, X., Huang, S., Liu, M., Chen, S., Full-scale blending treatment of fresh MSWI leachate with municipal wastewater in a wastewater treatment plant. Waste Management, 34, 2305-2311 (2014). https://doi.org/10.1016/j.wasman.2014.06.019

Water Environment Federation (WEF), Industrial Wastewater Management, Treatment and Disposal. 3a Edição - Manual of Practice no. FD-3, McGraw Hill, 2008.

Welander, U., Henrysson, T., Welander, T. Nitrification of landfill leachate using suspended-carrier biofilm technology. Water Research, 31, 2351-2355 (1997). https://doi.org/10.1016/S0043-1354(97)00080-8

Wiesmann, U., Choi, I. S., Dombrowski, E. M. Fundamental of Biological Wastewater Treatment. Wiley-VCH (2007). https://doi. org/10.1002/9783527609604

Wiszniowsk, J., Robert, D., Surmacz-Gorska, J., Miksch, K., Weber, J. V. Landifill Leachate Treatment Methods: A Review. Environmental Chemistry Letters, 4, 51-61 (2006). https://doi. org/10.1007/s10311-005-0016-Z 
